\title{
TRYPANOSOMA AVIUM INCIDENCE, PATHOGENICITY AND RESPONSE TO MELARSOMINE IN FALCONS FROM KUWAIT
}

\author{
W. TARELLO*
}

\section{Summary :}

Epidemiological and clinical studies on Trypanosoma avium are lacking in the Middle East. The aims of this study were to determine the T. avium incidence in falcons from Kuwait, report clinical signs and find an effective therapy. Blood smears from 921 diseased and 56 healthy falcons were examined between May 2003 and April 2004. 12 birds (1.3\%) were found infected by $T$. avium and ten of these were treated with melarsomine (Cymelarsan ${ }^{\circledR}$ ) at a dosage of $0.25 \mathrm{mg} / \mathrm{kg}$ intramuscularly for four days. All affected birds presented clinical signs, including incapacity of flying high, poor appetite, lethargy, loosing weight, weakness, dyspnoea and death. Signs disappeared within 1-7 days after administration of melarsomine. Trypomastigotes were not detected in blood smears made 1-7 days after the end of therapy. This study suggests that T. avium induces disease in falcons and that melarsomine can be an effective therapy eliminating both clinical signs and circulating trypomastigotes.

KEY WORDS : Trypanosoma avium, falcon, bird of prey, pathogenicity, chemotherapy, melarsomine, Kuwait.
Résumé : INCIDENCE DE TRYPANOSOMA AVIUM, SYMPTOMATOLOGIE ET RÉPONSE AU TRAITEMENT AVEC LA MÉLARSOMINE CHEZ LES FAUCONS AU KOWEIT

Au Moyen-Orient, il y a un manque d'études épidémiologiques et cliniques sur Trypanosoma avium. La présente étude avait pour objectifs de déterminer l'incidence de T. avium chez les faucons au Koweit, de décrire les signes cliniques et de trouver une thérapie efficace. Du mois de mai 2003 au mois d'avril 2004, les frottis sanguins de 921 faucons malades et de 56 faucons sains ont été examinés. 12 oiseaux (1,3\%) étaient porteurs de $T$. avium et dix ont été soumis a un traitement intramusculaire de mélarsomine (Cymelarsan ${ }^{\circledR}$ ) à la posologie de 0,25 mg/kg par jour pendant quatre jours. Tous les oiseaux atteints présentaient des signes cliniques incluant une incapacité au haut vol, un manque d'appétit, une léthargie, une perte de poids, un épuisement général, une difficulté respiratoire et, pour certains, la mort. Les signes cliniques ont disparu en un à sept jours et on n'a plus trouvé de trypomastigotes dans le sang une semaine après la thérapie. Cette étude suggère que T. avium provoque une maladie chez les faucons de chasse et que la mélarsomine peut être un traitement de choix en éliminant les trypomastigotes et les signes cliniques.

MOTS CLÉS : Trypanosoma avium, faucon, oiseau de proie, symptomatologie, chimothérapie, mélarsomine, Koweit.

observations made during the initial part of this study indicate that clinical signs are present in captive falcons infected by T. avium. This paper reports the incidence of T. avium in a large population of sick falcons, the clinical signs observed, and the response to melarsomine (Cymelarsan ${ }^{\circledR}$, Merial), a trypanocide drug that has never previously been used in birds infected by $T$. avium.

\section{MATERIALS AND METHODS} in the Middle East. Current scientific knowledge suggests that no pathogenicity is associated with avian trypanosomosis (Peirce, 2003). However, preliminary

\footnotetext{
* International Veterinary Hospital, P.O. Box 9275, 61003 Ahmadi, Kuwait.

Tel.: 009653261421 - Fax: 009653261392

E-mail: wtarello@yahoo.it
}

$\mathrm{F}$ rom early May 2003 to the end of April 2004, examinations for the presence of Trypanosoma avium were made on Diff-Quick-stained blood smears from 921 diseased birds of prey and 56 healthy control falcons, belonging to three species (Falco peregrinus, Falco cherrug and Falco rusticolus).

Blood samples were collected from the brachial vein. All falcons were used for hunting, a category given 
constant special care in the Middle East. Consequently, reports on their health status and clinical signs were precise. Information evaluated included signalement, origin, date of consultation, clinical signs, intensity of infection $(+=$ low,$++=$ moderate, $+++=$ high, $++++=$ very high) and melarsomine (Cymelarsan ${ }^{\circledR}$, Merial) therapy outcomes (Table I). Melarsomine, a registered medication for the treatment of Trypanosoma evansi in camels ("surra"), was injected by IM route at the recommended daily dose of $0.25 \mathrm{mg} / \mathrm{kg}$ (Touratier, 1992) for four consecutive days. Clinical and haematological outcomes were checked within 1-7 days after the end of therapy.

\section{RESULTS}

T welve falcons out of $921(1,3 \%)$ were infected (Table I). None of the 56 healthy controls was carrying T. avium. In total, 977 birds of prey were examined. Trypanosome infections were detected between August and January, but not between February and July. Clinical signs were present in all affected raptors, and no concurrent diseases could be detected in any of them. Sudden death occurred in one case. Signs more often reported were incapacity of flying high $(7 ; 58.3 \%)$, poor appetite $(6 ; 50 \%)$, lethargy $(5 ; 41.7 \%)$, loose of weight $(5 ; 41.7 \%)$, weakness $(3 ; 25 \%)$ dyspnoea $(2 ; 16.7 \%)$ and a cessation of molting $(2 ; 16.7 \%)$. Within seven days after the end of therapy, the ten treated birds presented complete clinical recovery with the disappearance of trypomastigotes (Table I)

\section{DISCUSSION}

$\int$ cattered past reports have pointed out that T. avium can cause fatal infections in birds (Baker, 1976; Mungomba et al., 1989). One falcon in the study group died before starting treatment, apparently confirming those previous observations. According to the recent literature, there was no evidence to indicate that T. avium is pathogenic (Peirce, 2003; Votypka et al., 2002).

This assumption does not seem to be based on verifiable facts but on the lack of direct research, since today only morphological (Yurchenko et al., 1999) and epidemiological informations (Kirkpatrick \& Lauer, 1985; Munoz et al., 1999) are available. Most of previous studies were carried out on wild animals captured and released after sampling (Rintamaki et al., 1999; Deviche et al., 2001; Holstad et al., 2003). Under such field conditions pathogenic effects are hard to assess. In domestic or semi-domesticated animals living in proximity to human beings, such as captive falcons,

\begin{tabular}{|c|c|c|c|c|}
\hline No. & $\begin{array}{l}\text { Species, sex, } \\
\text { age, weight, origin } \\
\text { and date of visit }\end{array}$ & $\begin{array}{l}\text { Duration } \\
\text { of } \\
\text { the disease }\end{array}$ & $\begin{array}{l}\text { Clinical signs and intensity } \\
\text { of infection (from }+ \text { to }++++ \text { ) }\end{array}$ & Therapy outcomes \\
\hline 15 & $\begin{array}{l}\text { Saker, F, } 4 \text { years, } 975 \text { gr, } \\
\text { Kuwait, } 25 \text { August } 2003\end{array}$ & 1 month & Poor appetite, lethargy, stopped moulting & Dead before starting the treatment \\
\hline $2 \mathrm{I}$ & $\begin{array}{l}\text { Peregrine, M, } 1 \text { year, } 640 \text { gr, } \\
\text { Pakistan, } 26 \text { August } 2003\end{array}$ & 1 week & Poor appetite, lethargy, loosing weight & Clinical and haematological recovery \\
\hline 35 & $\begin{array}{l}\text { Saker, F, } 4 \text { years, } 1114 \text { gr, } \\
\text { Kuwait, } 29 \text { August } 2003\end{array}$ & 3-5 days & $\begin{array}{l}\text { Lethargy } \\
\qquad(++)\end{array}$ & Clinical and haematological recovery \\
\hline 45 & $\begin{array}{l}\text { Saker, F, } 3 \text { years, } 985 \text { gr, } \\
\text { Russia, } 29 \text { September } 2003\end{array}$ & 2 months & Poor appetite, stopped moulting, loosing weight & Clinical and haematological recovery \\
\hline $5 \mathrm{I}$ & $\begin{array}{l}\text { Peregrine, M, } 4 \text { years, } 841 \text { gr, } \\
\text { Kuwait, } 28 \text { October } 2003\end{array}$ & 10 days & Poor appetite, dyspnoea, weakness & Clinical and haematological recovery \\
\hline 65 & $\begin{array}{l}\text { Saker, M, } 2 \text { years, } 850 \text { gr, } \\
\text { Kuwait, } 15 \text { November } 2003\end{array}$ & 1 week & Weakness, not flying high, blood in the stool & Clinical and haematological recovery \\
\hline $7 \mathrm{I}$ & $\begin{array}{l}\text { Peregrine, M, } 1 \text { year, } 608 \text { gr, } \\
\text { Iraq, } 26 \text { November } 2003\end{array}$ & 1 week & $\begin{array}{l}\text { Lethargy, loosing weight } \\
\qquad(++++)\end{array}$ & Clinical and haematological recovery \\
\hline 8 & $\begin{array}{l}\text { Saker, M, } 4 \text { years, } 900 \text { gr, } \\
\text { Kuwait, } 26 \text { November } 2003\end{array}$ & 10 days & Poor appetite, not flying high, loosing weight & Clinical and haematological recovery \\
\hline 95 & $\begin{array}{l}\text { Saker, F, } 1 \text { year, } 1068 \text { gr, } \\
\text { Kuwait, } 6 \text { December } 2003\end{array}$ & 1 month & Weakness, not flying high, dyspnoea & Treatment was denied \\
\hline $10 \mathrm{I}$ & $\begin{array}{l}\text { Peregrine, M, } 1 \text { year, } 926 \text { gr, } \\
\text { Kuwait, } 10 \text { January } 2004\end{array}$ & 1week & Not flying high, haematoma on the back & Clinical and haematological recovery \\
\hline 11 & $\begin{array}{l}\text { Saker, M, } 1 \text { year, } 790 \text { gr, } \\
\text { Iraq, } 21 \text { January } 2004\end{array}$ & 1 month & Poor appetite, lethargy, not flying high & Clinical and haematological recovery \\
\hline 12 & $\begin{array}{l}\text { Saker, F, } 3 \text { years, } 1,000 \text { gr, } \\
\text { Kuwait, } 29 \text { January } 2004\end{array}$ & 1 month & $\begin{array}{l}\text { Weakness, loosing weight, not flying high } \\
\qquad(++++)\end{array}$ & Clinical and haematological recovery \\
\hline
\end{tabular}

Table I. - Trypanosoma avium and response to therapy in 12 falcons from Kuwait 
pathogenic effects are easier to detect and to describe. This seems to be the first attempt to study clinical signs and the response to therapy of $T$. avium infection in captive birds of prey. The results obtained indicate the constant presence of pathogenic effects and 9\% mortality rate (Table I). Fifty-six healthy controls proved negative for $T$. avium, leading to the exclusion of healthy carriers in the study group. The disappearance of clinical signs and of trypanosomes shortly after trypanocide therapy with melarsomine indirectly confirmed that the pathogenic signs were linked to the presence of trypanosomes.

The identification of trypomatigotes in blood smears is the diagnostic test for trypanosomosis suggested by the OIE (OIE, 2000). Flagellate bodies observed in the blood from the 12 falcons showed shapes and sizes in accordance with the morphological features of Trypanosoma avium (Peirce, 2003). Although blood samples were always obtained from the brachial vein, it is acknowledged that there is no significant difference between T. avium prevalence in blood collected from the brachial vein or deep circulation (Hosltad et al., 2003). Thus, the incidence rate of $1.3 \%$ obtained in this study should not be controversial with regard to the sampling site, although blood cultures may reveal a much higher prevalence. As an example, $1.2 \%$ of 259 birds of prey from southern New Jersey showed circulating Trypanosoma spp., while blood cultures from 142 of these raptors revealed a prevalence of $41.5 \%$ (Kirkpatrick \& Lauer, 1985). It has been noted that the examination of stained blood smears will only show trypanosomes when present in the host at high levels (Peirce, 2003). This might explain the observation of clinical signs in infected birds, since it seems reasonable to assume that the higher the number of parasites the more pathogenic is their action.

The $1.3 \%$ incidence reported here is low if compared with studies from areas at higher latitudes (Rintamaki et al., 1999; Deviche et al., 2001; Holstad et al., 2003), taking also into account that the population examined includes 921 'diseased' falcons and not one healthy falcon

However, results from studies carried out on freeranging falcons admitted to wildlife rescue centres, accordingly to be considered 'diseased', are overlapping. In fact, 190 diseased falcons from Spain were found trypanosome-free (Munoz et al., 1999), and only $1.2 \%$ of 259 diseased birds of prey from USA were found to carry trypanosomes (Kirkpatrick \& Lauer, 1985). Unfortunately, clinical signs were not recorded and no therapy was suggested.

The abundance of vectors enhances parasite transmission during favouring seasons (Rintamaki et al., 1999). This observation is in agreement with the results of this one-year study since all cases were recorded between August and January and none between February and July (Table I), apparently indicating a seasonal occurrence.

\section{REFERENCES}

BAKER J.R. Biology of trypanosomes of birds. In: Biology of the Kinetoplastida. Lumsden W.H.R. \& Evans D.A. (eds). Academic Press, New York, 1976, 131-174.

Deviche P., Greiner E.C. \& MANTECA X. Interspecific variability of prevalence in blood parasites of adult passerine birds during the breeding season in Alaska. Journal of Wildlife Diseases 2001, 37, 28-35.

Holstad P.R., Anwar A., IEzhova T. \& Skorping A. Standard sampling techniques underestimate prevalence of avian hematozoa in willow ptarmigan (Lagopus lagopus). Journal of Wildlife Diseases 2003, 39, 354-358.

KirKPATRICK C.E. \& LAUER D.M. Hematozoa of raptors from southern New Jersey and adjacent areas. Journal of Wildlife Diseases, 1985, 21, 1-6.

Mungomba L.M., Molyneaux D.H. \& Wallbanks K.R. Host-parasite relationship of Trypanosoma corvi in Ornithomyia avicularia. Parasitology Research, 1989, 75, 167-174.

Munoz E., Ferrer D., Molina R. \& Adlard R.D. Prevalence of haematozoa in birds of prey in Catalonia, north-east Spain. Veterinary Record, 1999, 144, 632-636.

OIE. Trypanosomosis. In: Manual of standard for diagnostic tests and vaccines 2000. www.oie.int/eng/normes/manual. Accessed August 20, 2004.

Peirce M.A. Haematozoa. In: Avian medicine. Samour J. (ed.). Elsevier Science, Edinburgh, 2003, 245-252.

Rintamaki P.T., Huhta E., Jokimaki J. \& Souires-Parsons D. Leucocytozoonosis and trypanosomiasis in redstarts in Finland. Journal of Wildlife Diseases, 1999, 35, 603-607.

Sehgal R.N., Jones H.I. \& Smith T.B. Host specificity and incidence of Trypanosoma in some African rainforest birds: a molecular approach. Molecular Ecology, 2001, 10, 23192327.

Votypka J., Obornik M., Volf P., Svobodova M. \& Lukes J. Trypanosoma avium of raptors (Falconiformes): phylogeny and identification of vectors. Parasitology, 2002, 125, 253263.

Votypka J. \& Svobodova M. Trypanosoma avium: experimental transmission from black flies to canaries. Parasitology Research, 2004, 92, 147-51.

TOURATIER L. Eleventh international meeting on Trypanosoma evansi: report of the Working Group. Paris, 17 May 1990. Revue Scientifique et Technique, 1992, 11, 275-304.

Yurchenko V., Hobza R., Benada O. \& Lukes J. Trypanosoma avium: large minicircles in the kinetoplast DNA. Experimental Parasitology, 1999, 92, 215-218.

Reçu le 16 septembre 2004 Accepté le 14 décembre 2004 